\title{
Preparation of Novel Fe Catalysts from Industrial By-Products: Catalytic Wet Peroxide Oxidation of Bisphenol A
}

Riikka Juhola,

Anne Heponiemi, $1 \square$

Email anne.heponiemi@oulu.fi

Sari Tuomikoski,

Tao Hu,

Tuomas Vielma, 2

Ulla Lassi, 1,2

1 Research Unit of Sustainable Chemistry, University of Oulu, P.O. Box 3000, 90014 Oulu, Finland

2 Kokkola University Consortium Chydenius, University of Jyväskylä, P.O. Box 567, 67701 Kokkola, Finland

\section{Abstract}

Biomass-based carbon residue (CR) was used as a support material for iron catalysts to degrade bisphenol A (BPA) in catalytic wet peroxide oxidation (CWPO). According to the results, $\mathrm{CR}$ and $\mathrm{Fe} / \mathrm{CR}$ catalysts are suitable materials for CWPO. The Fe catalysts were prepared by either incipient wet impregnation or wet impregnation methods with an iron chloride solution. The specific surface area of the prepared catalysts was $17-91 \mathrm{~m}^{2} \mathrm{~g}^{-1}$, and it remained the same after the oxidation experiments. The CWPO experiments were carried out batch-wise at $\mathrm{c}(\mathrm{BPA})=60 \mathrm{mg} \mathrm{L}^{-1}, \mathrm{c}\left(\mathrm{H}_{2} \mathrm{O}_{2}\right)=1.5 \mathrm{~g} \mathrm{~L}^{-1}, \mathrm{c}$ (catalyst) $=1-2 \mathrm{~g} \mathrm{~L}^{-1}, \mathrm{~T}=50^{\circ} \mathrm{C}$ and at the initial $\mathrm{pH}$. The $5.0 \mathrm{Fe} / \mathrm{CR}$ catalyst 
was found to be active with BPA removal and total organic carbon (TOC) conversion of 83 and $64 \%$, respectively, and was the most stable catalyst with negligible iron leaching during the $3 \mathrm{~h}$ experiment.

\section{Keywords}

Bisphenol A

Catalytic wet peroxide oxidation (CWPO)

Fe-catalyst

Biomass

\section{Introduction}

The world's freshwater resources continue to deteriorate due to pollution and climate change. In many countries, such as India [1], the Netherlands [2] and Finland [3], the aquatic environment has been found to contain trace levels ( $\mu \mathrm{g} \mathrm{L}^{-1}$ or $n g \mathrm{~L}^{-1}$ or even lower) of various pollutants, including industrial compounds, personal care products, endocrine-disrupting chemicals (EDCs) etc. [4, 5, 6]. These compounds enter the aquatic environment from industrial and municipal effluents [7] because the existing wastewater treatment plants (WWTPs) were designed to remove mainly inorganic substances, nutrients and pathogens, not trace levels of organic refractory compounds [8]. Therefore, more efficient water treatment methods and sustainable water reuse technologies are needed.

Bisphenol A (2,2-bis(4-hydroxyphenyl)propane, BPA), classified as an EDC by the U.S. Environmental Protection Agency [9], is one of the compounds found in various bodies of water $[10,11]$. BPA is a synthetic organic substance that has been mainly used to produce polycarbonate plastics and epoxy resins [12]. Other applications include thermal paper, paper coatings and building materials [13]. BPA has been rated a high-volume production chemical with a global production rate of more than $5 \mathrm{Mt}$ in 2015 [14]. According to the U.S. EPA [9], more than 1 million pounds of BPA leaches into U.S. environment every year. Several studies have shown that BPA has harmful effects on animals due to estrogenic activity, such as inducing feminization [15] 
and by disruption of the development of the reproductive system [16, 17]. To date, various techniques have been implemented to treat BPA, including ozonation [18], Fenton/photo-Fenton [19, 20, 21] and adsorption [22]. Ozonation has high oxidation potential in the degradation of BPA, but the process is not economical due to the high operational costs [23]. Fenton/photo-Fenton is an economical treatment method, but the optimal reaction conditions are limited to a $\mathrm{pH}$ of less than 4 , and the process produces iron-containing sludge as secondary waste [24]. The adsorption process is highly effective and easily conducted, but it also produces secondary waste. The adsorbent has to be regenerated or treated with another technique, which increases the operational costs [25].

Compared to these purification technologies, catalytic wet peroxide oxidation (CWPO) has shown excellent removal efficiency for several organic compounds, such as phenol, carboxylic acids and industrial effluents [26, 27, 28, 29, 30, 31]. CWPO was adapted from a classical Fenton process [32], which has been referred to as an economical alternative to wastewater treatment techniques [33] because it requires only basic equipment and operates at ambient-like pressure and temperature $[34,35]$. During this process, hydrogen peroxide $\left(\mathrm{H}_{2} \mathrm{O}_{2}\right)$ decomposes in the presence of the catalyst (typically $\mathrm{Fe}$ or $\mathrm{Cu}$ salts) producing highly reactive hydroxyl radical species $\left(\mathrm{OH}^{\prime}\right)$ that degrade most of the organic pollutants present in the wastewater [36]. Compared to the traditional Fenton process, CWPO can be conducted over a broad pH range by using heterogeneous catalysts [37]. Improvements, especially in finding an optimal catalyst, would make this technique even more efficient, and materials, such as pillared clays [38], silica and alumina [39], have been tested in CWPO. In recent years, carbonsupported metal catalysts have interested many researchers as carbon materials have been found to possess unique properties, such as good stability under acidic and basic conditions and a high specific surface area that leads to highly dispersed metal phases [40, 41]. According to the literature to date, only a few studies have used carbon-based catalysts in the CWPO process [42], but the studies showed very promising results in this field of study. Many of these studies were conducted by using commercial activated carbons [43, 44, 45, 46]; however, environmentally friendly alternatives that are more cost- 
effective are needed. Industrial processes generate various waste materials and by-products, and all utilization applications are preferred to landfilling. Moreover, within the European Union (EU) region, legislation restricts the landfilling of waste materials that contain more than $10 \%$ organic carbon [47]. Therefore, an alternative use for waste materials, such as recycling, has to be found. Although there has been interest in using the carbon-based waste materials in different types of wastewater treatment applications, such as adsorption [48, 49, 50], only a few studies in the literature focused on the preparation of carbonsupported catalysts from waste material in CWPO. In the present study, in which waste material formed during the biomass gasification process, carbon residue (CR) was used as a carbon-based catalyst support. Carbonaceous materials are known to contain metal impurities such as iron and their presence may increase the catalytic activity [51]. Also, the impregnated iron has been shown to enhance the catalytic oxidation of various compounds using carbon-based catalyst in CWPO in several works $[35,52,53,54,55,56]$.Therefore iron was chosen as an active metal for the CR support.

The objective of this study was to investigate CWPO of BPA using a biomass-based $\mathrm{CR}$ as a support for iron catalysts. Iron was incorporated on the CR by incipient wet impregnation or wet impregnation. The physical and chemical states of the prepared catalysts were characterized with inductively coupled plasma optical emission spectroscopy (ICP-OES), Brunauer-Emmet-Teller (BET) equations, $\mathrm{X}$-ray diffraction (XRD), diffuse reflectance infrared Fourier transform spectroscopy (DRIFTS), and field emission scanning electron microscopy (FESEM). The CWPO results were analyzed in terms of BPA removal and total organic carbon (TOC) conversion using highperformance liquid chromatography (HPLC) and TOC analytical techniques, respectively. The possible leaching of active iron from the catalysts was determined with ICP-OES. Kinetics and by-products were also evaluated.

\section{Experimental}

This section presents the characterization techniques and analytical methods carried out to determine the physical and chemical state of the 
fresh and used catalysts, as well as to assess the activity and stability of the prepared iron catalysts in catalytic wet peroxide oxidation.

\subsection{Materials}

The CR used in this study was waste material obtained from a pilotscale biomass gasification plant (Sievi, Finland) that involved a $150 \mathrm{~kW}$ airblown downdraft gasifier operating at a temperature of about 1000 ${ }^{\circ} \mathrm{C}$. Finnish wood biomass was used as fuel for the gasifier. Based on previous studies, the carbon residue contained soluble nutrients. The main components were calcium $\left(42.3 \mathrm{~g} \mathrm{~kg}^{-1}\right)$ and sodium $\left(71 \mathrm{mg} \mathrm{kg}^{-1}\right)$. In addition, the $\mathrm{CR}$ also contained metals, for example, copper $\left(130 \mathrm{mg} \mathrm{kg}^{-1}\right)$ and zinc $\left(134 \mathrm{mg} \mathrm{kg}^{-1}\right)$. The $\mathrm{pH}$ of the material was 9, the total carbon content $15 \%$, the specific surface area $15 \mathrm{~m}^{2} \mathrm{~g}^{-1}$, the pore size $16 \mathrm{~nm}$ and the pore volume $0.06 \mathrm{~cm}^{3} \mathrm{~g}^{-1}$. The detailed properties of the material are presented elsewhere [57].

Before use, the carbon residue was dried at $105^{\circ} \mathrm{C}$ to achieve constant weight and then further ground and sieved so the particles were smaller less than $150 \mu \mathrm{m}$. The CR was thoroughly washed using deionized (DI) water until neutral $\mathrm{pH}$ was reached, dried again at $105^{\circ} \mathrm{C}$ overnight and stored in a desiccator. The chemicals, including ferric chloride $(\geq 98 \%$, Merck), bisphenol A ( $\geq 99 \%$, Sigma-Aldrich), hydrogen peroxide (30\% w/w, Merck), hydrochloric acid $\left(0.09983 \pm 0.00041 \mathrm{~mol} \mathrm{~L}^{-1}, \mathrm{FF}-\right.$ Chemicals) and sodium hydroxide $\left(0.09992 \pm 0.0073 \mathrm{~mol} \mathrm{~L}^{-1}, \mathrm{FF}-\right.$ Chemicals), were reagent grade. Commercial activated carbon Norit (AC Norit, Norit ${ }^{\circledR}$ GAC 1240 Plus) from coconut peel was used as a reference material.

\subsection{Preparation of the Catalysts}

Three iron-loaded carbon residue-derived catalysts (Fe/CR) were prepared by either incipient wet impregnation or wet impregnation to the $\mathrm{CR}$ with an aqueous solution of ferric chloride. The $\mathrm{Fe}$ concentrations were adjusted to obtain 2.5, 5.0 and $33 \% \mathrm{Fe}$ content $(\mathrm{w} / \mathrm{w})$ on the catalyst, and the corresponding catalysts were thus named $2.5 \mathrm{Fe} / \mathrm{CR}, 5.0 \mathrm{Fe} / \mathrm{CR}$ and $33 \mathrm{Fe} / \mathrm{CR}$, respectively. 
The multi-step method presented by Chang et al. [44] was used to impregnate the $\mathrm{CR}$ with iron $(2.5 \mathrm{Fe} / \mathrm{CR})$. After the incipient impregnation, the mixture was stirred for $16 \mathrm{~h}$ at room temperature and at initial $\mathrm{pH}$. Then, the $2.5 \mathrm{Fe} / \mathrm{CR}$ catalyst was separated from the liquid phase and dried at $105^{\circ} \mathrm{C}$ overnight. These steps were repeated five times in order to achieve higher iron content and stability for the $2.5 \mathrm{Fe} / \mathrm{CR}$ catalyst.

For the $5.0 \mathrm{Fe} / \mathrm{CR}$ and $33 \mathrm{Fe} / \mathrm{CR}$ catalysts, a one-step method for iron wet impregnation was performed. In the preparation of the $5.0 \mathrm{Fe} / \mathrm{CR}$ catalyst, $8 \mathrm{~mL}$ of DI water per gram of $\mathrm{CR}$ and $8 \mathrm{~mL}$ of $1 \mathrm{M}$ sodium hydroxide were added to the $\mathrm{Fe} / \mathrm{CR}$ mixture to increase the $\mathrm{pH}$ to $8-9$ and to form ferric hydroxide. The $33 \mathrm{Fe} / \mathrm{CR}$ catalyst was prepared by adjusting the $\mathrm{pH}$ from initial 2-2.5 to neutralize only part of the $\mathrm{FeCl}_{3}$ solution. After the $\mathrm{pH}$ was adjusted, the suspensions were slowly evaporated using a rotating evaporator at $40-50{ }^{\circ} \mathrm{C}$ under reduced pressure and further dried at $105^{\circ} \mathrm{C}$ overnight.

After impregnation, the dried catalysts were ground and sieved to ensure the particles were smaller less than $150 \mu \mathrm{m}$. Finally, the catalysts were calcined in a furnace at $280^{\circ} \mathrm{C}$ for $5 \mathrm{~h}$ under nitrogen gas flow $\left(15 \mathrm{~L} \mathrm{~min}^{-1}\right)$.

\subsection{Catalyst Characterization}

The iron content of the fresh and used catalysts was measured with ICPOES (Perkin Elmer Optima 5300 DV). Sorption-desorption isotherms of nitrogen at $-196{ }^{\circ} \mathrm{C}$ were used to determine specific surface areas and pore volumes of the carbon products using the Micrometrics ASAP 2020 instrument. The specific surface areas and the pore volumes were calculated using BET and Barrett-Joyner-Halenda (BJH) equations, respectively. Powder XRD patterns for the phase identification of iron on the catalysts were obtained using the PANalytical X'pert Pro diffractometer system with the $\mathrm{Cu} \mathrm{K} \alpha$ ray at $45 \mathrm{kV}$ and $40 \mathrm{~mA}(\lambda=$ $1.5406 \AA$ ). Diffractograms were collected in the $2 \theta$ range from $5^{\circ}$ to $80^{\circ}$ using a scan speed of $0.019^{\circ} \mathrm{s}$. The diffractograms were compared to the Powder Diffraction File standards from the International Centre for Diffraction DATA (ICDD). The diffuse reflectance mode was used to 
record the DRIFTS (Brüker PMA 50 Vertex $80 \mathrm{~V}$ ) of the AC, CR and $\mathrm{Fe} / \mathrm{CR}$ catalysts to identify the possible functionality of these samples. The baseline was measured with $\mathrm{KBr}$, which was also used for the dilution of the samples (1:100). In each experiment, the sample chamber was purged with nitrogen $\left(100 \mathrm{~mL} \mathrm{~min}^{-1}\right)$, continuously heated at a rate of $10{ }^{\circ} \mathrm{C}$ per minute to the target temperature $\left(105^{\circ} \mathrm{C}\right)$ and maintained at that temperature for $1 \mathrm{~h}$. Measurements were obtained in the range of $400-4000 \mathrm{~cm}^{-1}$ with a resolution of $4 \mathrm{~cm}^{-1}$ and 100 scans per minute. The surface morphology of the fresh and used Fe/CR catalysts was investigated using a Zeiss ULTRA plus FESEM combined with energy-dispersive X-ray spectroscopy (EDS) for element mapping.

\subsection{Catalytic Wet Peroxide Oxidation of BPA and} Kinetic Measurements

The catalysts were studied in the catalytic wet peroxide oxidation of BPA aqueous solution. Please take the full stop and enter off.

(60 $\mathrm{mg} \mathrm{L}^{-1}$ ). The amount of hydrogen peroxide needed for complete mineralization of the organic carbon was estimated to be 5.6 times the mass ratio of $\mathrm{H}_{2} \mathrm{O}_{2}$ /BPA using the following reaction (Eq. 1):

$$
\mathrm{C}_{15} \mathrm{H}_{16} \mathrm{O}_{2}+36 \mathrm{H}_{2} \mathrm{O}_{2} \rightarrow 15 \mathrm{CO}_{2}+44 \mathrm{H}_{2} \mathrm{O}
$$

The oxidation reaction was carried out in a three-necked $500 \mathrm{~mL}$ round bottom flask, equipped with a magnetic stirrer and a reflux condenser, and the reactor was placed in a water bath. The powdered catalyst or carbon residue ( 1 or $2 \mathrm{~g} \mathrm{~L}^{-1}$ ) was introduced into $160 \mathrm{~mL}$ of an aqueous BPA solution $\left(60 \mathrm{mg} \mathrm{L}^{-1}\right)$ under continuous stirring. The experiments were run at $50{ }^{\circ} \mathrm{C}$ and the initial $\mathrm{pH}$ for $3 \mathrm{~h}$. After the temperature was stabilized, a solution of $0.15 \% \mathrm{H}_{2} \mathrm{O}_{2}$ was added to the reactor, which was taken as the starting point of the reaction $(t=0) . \mathrm{H}_{2} \mathrm{O}_{2}$ was added during the experiment as doses $\left(1.5 \mathrm{~g} \mathrm{~L}^{-1}\right)$ so that the stoichiometric amount of the $\mathrm{H}_{2} \mathrm{O}_{2}$ /BPA ratio was achieved. Samples of the reaction medium were taken periodically and filtered through $0.45 \mu \mathrm{m}$ filter paper. Dissolved oxygen content and $\mathrm{pH}$ (Hach Lange HQ40d portable meter, LDO and $\mathrm{pH}$ probes) were followed during the experiment. To study the possible adsorption of BPA on the catalyst surface, adsorption 
experiments were performed in the same reaction conditions without adding the oxidizing agent, $\mathrm{H}_{2} \mathrm{O}_{2}$.

\subsection{Analytical Methods}

The bisphenol A concentration and the oxidation by-products were identified and quantified with HPLC equipped with an ultraviolet -visible (UV-Vis) detector, using a $226 \mathrm{~nm}$ wavelength (Shimadzu SPD-10A). The mixture of acetonitrile (ACN, 45\%) and formic acid (FA, $0.1 \%$ ) were used as the eluent (flow rate $0.5 \mathrm{~mL} \mathrm{~min}^{-1}$ ), and the compounds was separated with the SunFire ${ }^{\mathrm{TM}}$ C18 $5 \mathrm{~m} 2.1 \times 100 \mathrm{~mm}$ column, operated at a temperature of $40^{\circ} \mathrm{C}$. Mineralization of the TOC in the wastewater and in the BPA samples was monitored by using the Skalar Formaes htFormacs ${ }^{\mathrm{HT}}$ Total Organic Content/Total Nitrogen analyzer. In this system, all organic and inorganic carbon in the sample was catalytically oxidized at $750-950^{\circ} \mathrm{C}$ to gaseous carbon dioxide. $\mathrm{CO}_{2}$ was detected with a non-dispersive infrared detector at a wavelength of $4.2 \mu \mathrm{m}$. The inorganic carbon content of the sample was measured with acidic oxidation, and the TOC of the sample was determined by subtracting the inorganic carbon content from the total carbon content. The amount of possible leached iron after the oxidation reactions was determined with an atomic absorption spectrophotometer (AAS, PerkinElmer AAnalyst 200) instrument, at a wavelength of $248.3 \mathrm{~nm}$.

AQ1

\section{Results and Discussion}

\subsection{Characterization of the Fresh Catalysts}

The iron content (determined with ICP-OES), together with the textural characteristics of the fresh catalysts, is presented in Table 1. In the case of the 5.0Fe/CR catalyst, prepared in basic conditions ( $\mathrm{pH} \mathrm{8-9),} \mathrm{the}$ iron content was in good agreement with the target value. The addition of iron per repetition to the $2.5 \mathrm{Fe} / \mathrm{CR}$ catalyst was $2.5 \mathrm{wt} \%$ at each repetition; that is, the theoretical amount of $\mathrm{Fe}$ on the support should have been $12.5 \mathrm{wt} \%$. However, the total amount of impregnated iron was $5.0 \mathrm{wt} \%$. Compared to results reported by Chang et al. [44] who used the same method, the difference might be because the carbon 
material was different. Furthermore, during the repetitions, part of the impregnated iron might have been re-dissolved into the liquid phase and some support material lost during the separation steps. Catalytic activity is related more to the high metal content than to the surface area [58], which was why a catalyst containing $33 \mathrm{wt} \%$ of iron was prepared. However, the iron content of that catalyst was $14 \mathrm{wt} \%$. As previously described, it is difficult to obtain high amounts of impregnated iron inside CR in one step. It has been reported that high iron content in the mixture produced a carbon with a smaller surface area [59]. The lack of impregnated iron might be because that there was not enough available surface area on the CR support.

\section{Table 1}

Iron content, BET surface area, total pore volume and relative distribution of micro-, meso- and macropores of fresh catalysts

\begin{tabular}{|c|c|c|c|c|c|c|}
\hline Catalyst & $\begin{array}{l}\text { Fe- } \\
\text { content } \\
(\%)\end{array}$ & $\begin{array}{l}\text { BET } \\
\text { surface } \\
\text { area }\left(\mathrm{m}^{2}\right. \\
\left.\mathrm{g}^{-1}\right)\end{array}$ & $\begin{array}{l}\text { Total pore } \\
\text { volume } \\
\left(\mathrm{cm}^{3} \mathrm{~g}^{-1}\right)\end{array}$ & $\begin{array}{l}V_{\text {Micro }} \\
(\%)\end{array}$ & $\begin{array}{l}V_{\text {Meso }} \\
(\%)\end{array}$ & $\begin{array}{l}V_{\text {Makro }} \\
(\%)\end{array}$ \\
\hline $2.5 \mathrm{Fe} / \mathrm{CR}$ & 5.0 & 62.8 & 0.096 & 5.66 & 77.9 & 16.4 \\
\hline $5.0 \mathrm{Fe} / \mathrm{CR}$ & 4.0 & 66.0 & 0.091 & 6.78 & 74.9 & 18.3 \\
\hline $33 \mathrm{Fe} / \mathrm{CR}$ & 14 & 17 & 0.074 & 1.11 & 46.8 & 52.1 \\
\hline $\mathrm{AC}$ & 0.21 & 923 & 0.434 & 13.3 & 13.9 & 73.6 \\
\hline CR & 0.20 & 91.3 & 0.119 & 6.89 & 76.6 & 16.5 \\
\hline
\end{tabular}

According to the results presented in Table 1, the surface area of the carbon residue was $91.3 \mathrm{~m}^{2} \mathrm{~g}^{-1}$. All the iron loaded catalysts showed that the surface area and the pore volume decreased with the increase in iron. This variation may indicate that the ferric species was immobilized in the pores of the $\mathrm{CR}$, leading to a reduction in the surface area. In addition, the higher iron content in the $33 \mathrm{Fe} / \mathrm{CR}$ catalyst led to a significantly lower surface area. These results are in line with those presented in the literature $[60,61]$. The surface area and the total pore volume were significantly higher in the reference material, commercial activated carbon (AC Norit). 
X-ray diffractograms of the powdered carbon residue support and $\mathrm{Fe}$ catalysts are presented in Fig. 1. The strong sharp peaks in the prepared $33 \mathrm{Fe} / \mathrm{CR}$ catalyst suggest good crystallinity of iron oxide. The major peaks for the $33 \mathrm{Fe} / \mathrm{CR}$ catalyst matched well with the crystalline iron species of hematite $\left(\mathrm{Fe}_{2} \mathrm{O}_{3}\right.$, the main peaks were at $2 \theta$ at $31.7^{\circ}, 33.1^{\circ}$, $35.6^{\circ}, 45.4^{\circ}$ and $56.4^{\circ}$, JCPDS: 01-089-0597). For comparison, the reflections obtained for the $2.5 \mathrm{Fe} / \mathrm{CR}$ catalyst at $2 \theta 26.6^{\circ}$ and $35.5^{\circ}$ corresponded to iron carbonate (JCPDS: 01-080-2679) whereas no iron was detected in the XRD pattern of the $5.0 \mathrm{Fe} / \mathrm{CR}$ catalyst. Instead, the reflections obtained for the $5.0 \mathrm{Fe} / \mathrm{CR}$ catalyst were found to be a match for sodium chloride (JCPDS: 01-076-3452). This result is reasonable as the used CR support had been found to contain soluble nutrients, such as sodium [57]. The $\mathrm{NaCl}$ content was further verified with EDS analysis, which indicated the presence of sodium $(3.3 \mathrm{wt} \%)$ and chlorine (6.7 wt \%). However, according to ICP-OES (Table 1), the $5.0 \mathrm{Fe} / \mathrm{CR}$ catalyst contained iron. Again, this result was confirmed with the EDS analysis, which showed $7.4 \mathrm{wt} \%$ of iron. Therefore, it might be possible that the probable small ferric oxo-hydroxide particles formed during the basic environment were precipitated in the macropores, not on the outer surface of carbon, and consequently could not be detected with XRD [38]. In addition, it was noticed that four peaks of $\mathrm{Fe}_{2} \mathrm{O}_{3}$ are overlapped with $\mathrm{NaCl}$ peaks at $2 \theta$ value of $\left(27.3^{\circ}, 31.7^{\circ}, 45.4^{\circ}\right.$ and $66.2^{\circ}$ ) (Fig. 2). The presence of $\mathrm{NaCl}$ might also explain the lower iron content of this particular catalyst (Table 1). Furthermore, the reflection pattern for the carbon residue support was obtained at $2 \theta 26.6^{\circ}, 29.4^{\circ}$, $32.9^{\circ}, 39.4^{\circ}, 43.1^{\circ}$ and $47.4^{\circ}$, corresponding to calcium carbonate (JCPDS: 01-078-3262). This was due to the high Ca content of the carbon residue [57].

\section{Fig. 1}

X-ray diffractograms of the fresh carbon residue support (1) and $\mathrm{Fe}$ catalysts (2-4). (plus) JCPDS:01-078-3262 $\left(\mathrm{CaCO}_{3}\right)$; (asterisk) JCPDS: 01-076-3452 ( $\mathrm{NaCl})$; (double quotes) JCPDS: 01-080-2679 $\left(\mathrm{FeCO}_{3}\right)$; (hash) JCPDS: 01-089-0597 $\left(\mathrm{Fe}_{2} \mathrm{O}_{3}\right)$ 


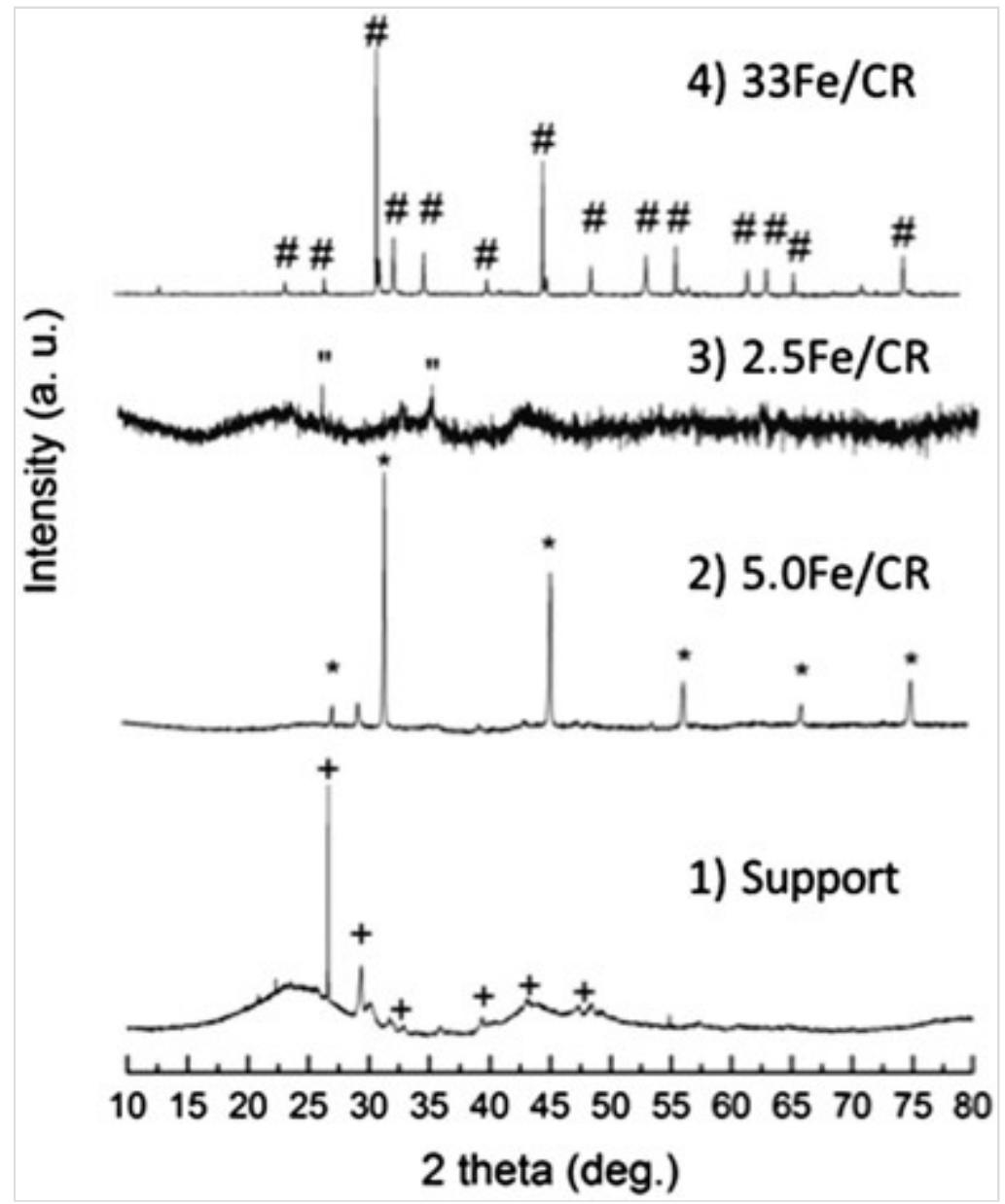

Fig. 2

The infrared spectrum for fresh activated carbon, carbon residue and $\mathrm{Fe}$ catalysts at $2500-800 \mathrm{~cm}^{-1}$

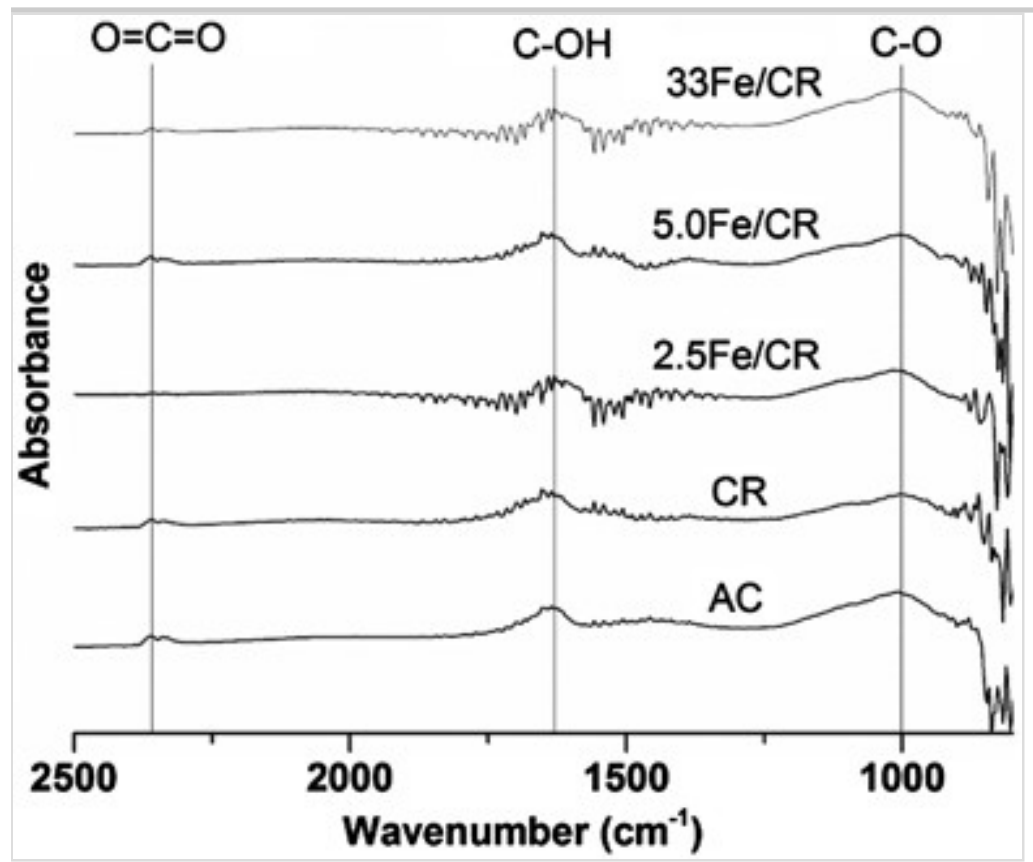


The DRIFTS method was used to qualitatively identify the possible functional groups of the carbon materials. The DRIFTS spectrum of the fresh samples is presented in Fig. 2. The CR and Fe catalysts have spectra comparable to the reference sample, commercial activated carbon. In all samples, a broad peak at around 3420-3440 $\mathrm{cm}^{-1}$ (not shown) was detected. This is the typical stretching of the O-H bond of the surface hydroxyl groups. Furthermore, at wavenumbers 2340 $-2360 \mathrm{~cm}^{-1}$ the peaks can be attributed to carbon dioxide [62]. Probably the highest peak at around $1640 \mathrm{~cm}^{-1}$ is characteristic of adsorbed water [63] while the broad peak at around wavenumber $1000 \mathrm{~cm}^{-1}$ is assigned to $\mathrm{CO}$ [64].

FESEM analysis was conducted to study the surface morphology of the fresh catalysts. The images obtained from FESEM are shown in Fig. 3, and they were in good agreement with the ICP-OES metal content results (Table 1$)$. The iron particles $(<<1 \mu \mathrm{m})$ are clearly seen and heterogeneously dispersed on the support in all prepared catalysts. Moreover, the structure of CR was found to be relatively porous and layered.

\section{Fig. 3}

SEM images of the fresh catalysts a $2.5 \mathrm{Fe} / \mathrm{CR}$, b $5.0 \mathrm{Fe} / \mathrm{CR}, \mathbf{c} 33 \mathrm{Fe} / \mathrm{CR}$ and $\mathbf{d}$ CR (magnification $\times 5000$ ). The iron particles are marked with an arrow 


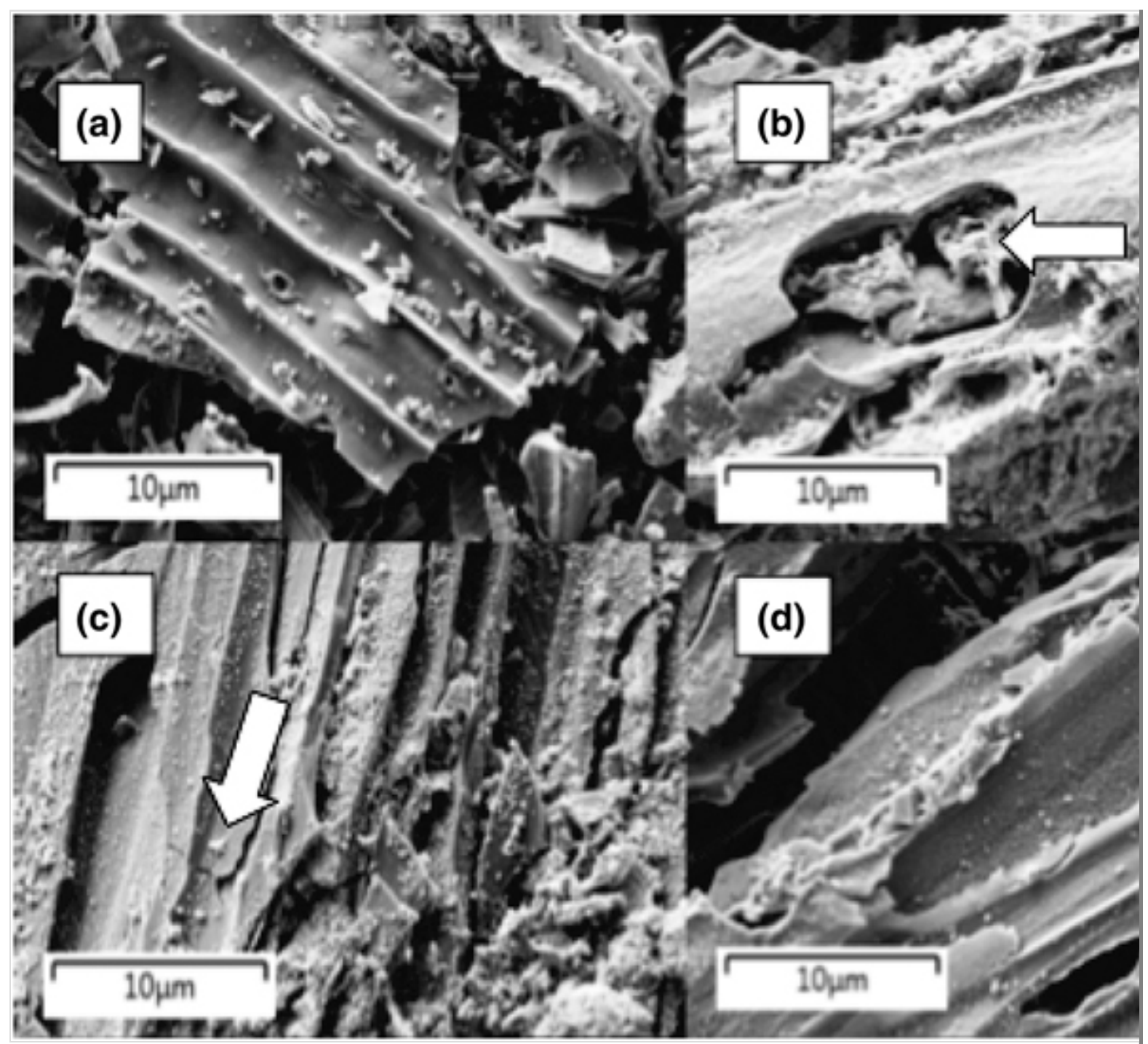

\subsection{Catalytic Wet Peroxide Oxidation of BPA by Different Catalysts}

The performance of the as-prepared catalysts was studied in the CWPO reactions that were carried out at $50{ }^{\circ} \mathrm{C}$ using $1.5 \mathrm{~g} \mathrm{~L}^{-1}$ of $\mathrm{H}_{2} \mathrm{O}_{2}$ as an oxidant. Before the BPA catalytic wet peroxide oxidation runs, an experiment without a catalyst was performed. The non-catalytic test indicated that with hydrogen peroxide $26 \%$ of BPA was removed after a $3 \mathrm{~h}$ experiment while the $\mathrm{pH}$ varied between 5.5 and 8.5 (Table 3). To evaluate the adsorption properties of the prepared catalysts, experiments without the oxidation agent were also conducted. In the adsorption tests, the catalyst amount was $1 \mathrm{~g} \mathrm{~L}^{-1}$.

The adsorption of BPA onto the catalysts in the absence of $\mathrm{H}_{2} \mathrm{O}_{2}$ was related to the BET surface area of the samples (Table 1), indicating that 
the higher the surface area the higher the removal of BPA by adsorption. The adsorption of BPA varied from 14 to $100 \%$, increasing in the order $33 \mathrm{Fe} / \mathrm{CR}<5.0 \mathrm{Fe} / \mathrm{CR}<2.5 \mathrm{Fe} / \mathrm{CR}<\mathrm{CR}<\mathrm{AC}$. The $2.5 \mathrm{Fe} / \mathrm{CR}$ and $5.0 \mathrm{Fe} / \mathrm{CR}$ catalysts were found to adsorb $37 \%$ and $32 \%$ of BPA, respectively, whereas the adsorption of BPA onto the $\mathrm{CR}$ was found to be $46 \%$. The adsorption process is known to depend strongly on the $\mathrm{pH}$ of the solution [65]. The $\mathrm{pH}$ values of the final solution varied from slightly basic (AC, CR, 5.0Fe/CR) to acidic $(2.5 \mathrm{Fe} / \mathrm{CR}, 33 \mathrm{Fe} / \mathrm{CR}$; Table 2). BPA is found in its molecular form at $\mathrm{pH}$ values below 8 [43] where the hydrophobic interactions ( $\pi-\pi$ interaction) enhance the adsorption of BPA. The situation changes when the $\mathrm{pH}$ value is higher than 8 due to the deprotonation of BPA. The reduction in the adsorption of BPA is partly due to the electrostatic repulsive interactions between the negatively charged carbon surface and the bisphenolate anion [43]. The $\mathrm{pH}$ values of the carbon slurries between the $2.5 \mathrm{Fe} / \mathrm{CR}$ and $5.0 \mathrm{Fe} / \mathrm{CR}$ catalysts after the heating up period, but just before starting the oxidation reaction (i.e., the $\mathrm{H}_{2} \mathrm{O}_{2}$ addition) were observed to vary significantly: For the $2.5 \mathrm{Fe} / \mathrm{CR}$ catalyst, the $\mathrm{pH}$ changed from the initial 6 to 3.1 whereas with the $5.0 \mathrm{Fe} / \mathrm{CR}$ catalyst, the change was in the opposite direction from the initial 6.9-8.6 to 7.3-8.9 (Table 2). The difference between the $\mathrm{pH}$ change could be due to the different preparation methods. The $5.0 \mathrm{Fe} / \mathrm{CR}$ catalyst was prepared at basic conditions whereas for the $2.5 \mathrm{Fe} / \mathrm{CR}$ catalyst the $\mathrm{pH}$ was not controlled. Although the surface properties of the prepared catalysts is not elucidated, it is clear that the $2.5 \mathrm{Fe} / \mathrm{CR}$ and $5.0 \mathrm{Fe} / \mathrm{CR}$ catalysts possess different characteristics based on the $\mathrm{pH}$ measurement. Therefore, the small difference $(5 \%)$ observed in the adsorption of BPA between the $2.5 \mathrm{Fe} / \mathrm{CR}$ and $5.0 \mathrm{Fe} / \mathrm{CR}$ catalysts might be caused by the difference in the $\mathrm{pH}$ as they have similar surface areas. Finally, all catalyst materials yielded much lower adsorption compared to the commercial AC Norit. The high adsorptive properties of carbonaceous materials have been widely presented in the literature $[43,44,45]$.

\section{Table 2}

The $\mathrm{pH}$ change, removal of BPA, TOC conversion and leaching of iron (compared to the initial amount of iron in the prepared Fe catalysts) after $3 \mathrm{~h}$ oxidation reaction 


\begin{tabular}{|c|c|c|c|c|c|c|}
\hline \multirow{2}{*}{ Catalyst } & \multicolumn{3}{|l|}{ pH } & \multirow{2}{*}{$\begin{array}{l}\text { BPA } \\
\text { removal } \\
(\%)\end{array}$} & \multirow{2}{*}{$\begin{array}{l}\text { TOC- } \\
\text { removal } \\
(\%)\end{array}$} & \multirow{2}{*}{$\begin{array}{l}\text { Iron } \\
\text { leached } \\
(\%)\end{array}$} \\
\hline & Initial & Slurry & Final & & & \\
\hline \multicolumn{7}{|c|}{ Catalyst load $1 \mathrm{~g} \mathrm{~L}^{-1}$} \\
\hline $2.5 \mathrm{Fe} / \mathrm{CR}$ & 5.5 & 3.2 & 3.1 & 100 & 39 & 3.6 \\
\hline $5.0 \mathrm{Fe} / \mathrm{CR}$ & 8.5 & 8.9 & 8.6 & 63 & 31 & - \\
\hline $33 \mathrm{Fe} / \mathrm{CR}$ & 6.9 & 3.2 & 3.0 & 100 & 51 & 3.4 \\
\hline $\mathrm{AC}$ & 8.0 & 8.8 & 8.1 & 100 & 70 & - \\
\hline $\mathrm{CR}$ & 6.2 & 8.4 & 8.5 & 65 & 33 & - \\
\hline \multicolumn{7}{|c|}{ Catalyst load $2 \mathrm{~g} \mathrm{~L}^{-1}$} \\
\hline $2.5 \mathrm{Fe} / \mathrm{CR}$ & 5.9 & 3.1 & 3.0 & 100 & 50 & 14.6 \\
\hline $5.0 \mathrm{Fe} / \mathrm{CR}$ & 6.9 & 7.3 & 7.8 & 83 & 64 & 0.10 \\
\hline $33 \mathrm{Fe} / \mathrm{CR}$ & 5.9 & 3.0 & 2.9 & 100 & 47 & 5.1 \\
\hline $\mathrm{AC}$ & 7.3 & 5.9 & 4.9 & 100 & 64 & - \\
\hline $\mathrm{CR}$ & 7.3 & 6.2 & 6.3 & 86 & 58 & - \\
\hline
\end{tabular}

According to the results, all materials showed similar catalytic activity. The catalysts with the highest load of iron, $2.5 \mathrm{Fe} / \mathrm{CR}$ and $33 \mathrm{Fe} / \mathrm{CR}$, performed the best catalytic activity in terms of BPA removal and TOC conversion with the two catalyst doses $\left(1-2 \mathrm{~g} \mathrm{~L}^{-1}\right)$. The $\mathrm{pH}$ of the effluent for the $2.5 \mathrm{Fe} / \mathrm{CR}$ and $33 \mathrm{Fe} / \mathrm{CR}$ catalysts during the CWPO reactions was found to change to more acidic; the final solution $\mathrm{pH}$ was around 3, which has been found in many previous studies to be the optimum value for the homogenous Fenton process [34, 54, 56, 66]. The possible explanation for the $\mathrm{pH}$ change may be related to the acidic nature of the $2.5 \mathrm{Fe} / \mathrm{CR}$ and $33 \mathrm{Fe} / \mathrm{CR}$ catalysts, as can be seen in Table 2. The $\mathrm{pH}$ of the carbon slurry changes from around 6 to 3 in both cases. Moreover, the low TOC conversion may also be due to the inefficient decomposition of $\mathrm{H}_{2} \mathrm{O}_{2}$. The mild operating temperature used in this study $\left(50^{\circ} \mathrm{C}\right)$ may lead to the $\mathrm{H}_{2} \mathrm{O}_{2}$ decomposition toward nonreactive species such as $\mathrm{O}_{2}$ or to auto-scavenging reactions if the 
decomposition of $\mathrm{H}_{2} \mathrm{O}_{2}$ occurs very quickly [41]. Furthermore, the leaching of $\mathrm{Fe}$ ions is known to be enhanced at low $\mathrm{pH}$ values [67, 68], and this can be seen in the case of the $2.5 \mathrm{Fe} / \mathrm{CR}$ and $33 \mathrm{Fe} / \mathrm{CR}$ catalysts (Table 2). These results are comparable with the studies reported by Rey et al. and Centi et al. [30,41]. Therefore, the contribution of homogenous and heterogenous Fenton processes had to be taken into consideration. According to Sabhi et al. [69], the homogenous Fenton process requires $50-80 \mathrm{mg} \mathrm{L}^{-1}$ of iron to maintain the reaction rate at a high level. However, the leached iron concentration found from the effluent was much lower (maximum of $27 \mathrm{mg} \mathrm{L}^{-1}$ of iron was observed). Therefore, it might be possible that the CWPO reaction in these operation conditions was mainly heterogeneous and did not go to completion as the iron concentration and the temperature $\left(50{ }^{\circ} \mathrm{C}\right)$ were relatively low. Moreover, finding the optimum $\mathrm{H}_{2} \mathrm{O}_{2}$ concentration is vital for the economy of the system. According to the dissolved oxygen measurements, the content of the dissolved oxygen remained steady for all the studied Fe catalysts, and no excess oxygen was available during the experiments, indicating that $\mathrm{H}_{2} \mathrm{O}_{2}$ was decomposed completely (as presented in Table 3). However, the dissolved oxygen content was significantly higher for $\mathrm{CR}$, and this may indicate that the decomposition of $\mathrm{H}_{2} \mathrm{O}_{2}$ proceeded mainly through $\mathrm{O}_{2}$ formation and not through $\mathrm{OH} \cdot$ [34]. Furthermore, the increase in the catalyst dose from 1 to $2 \mathrm{~g} \mathrm{~L}^{-1}$ did not show a significant difference in the BPA removal or TOC conversion for the $2.5 \mathrm{Fe} / \mathrm{CR}$ and $33 \mathrm{Fe} / \mathrm{CR}$ catalysts (Table 2 ). Further, the reference material, commercial AC Norit, was found to remove BPA completely, but this removal was mainly due to the adsorption of BPA, not the catalytic performance of the material.

\section{Table 3}

Dissolved oxygen content of BPA samples during the catalytic hydrogen peroxide oxidation experiments

\begin{tabular}{|l|l|l|l|l|l|l|l|}
\hline $\begin{array}{l}\text { Dissolved } \\
\mathbf{O}_{2}(\mathbf{m g ~ L} \\
\mathbf{1})\end{array}$ & $\begin{array}{l}\text { Non- } \\
\text { catalytic }\end{array}$ & $\mathbf{2 . 5 F e / C R}$ & $\mathbf{5 . 0 F e} / \mathbf{C R}$ & $\mathbf{3 3 F e} / \mathbf{C R}$ & $\mathbf{A C}$ & $\mathbf{C R}$ \\
\hline Initial & 9.7 & 9.7 & 9.1 & 9.8 & 9.9 & 9.9 \\
\hline & $5.8-6.0$ & $5.6-6.2$ & $5.9-6.3$ & $5.8-6.7$ & & \\
\hline
\end{tabular}




\begin{tabular}{|l|l|l|l|l|l|l|}
\hline $\begin{array}{l}\text { Dissolved } \\
\mathbf{O}_{2}\left(\mathbf{m g} \mathbf{L}^{-}\right.\end{array}$ & $\begin{array}{l}\text { Non- } \\
\text { catalytic }\end{array}$ & $\mathbf{2 . 5 F e / C R}$ & $\mathbf{5 . 0 F e} / \mathbf{C R}$ & $\mathbf{3 3 F e / C R}$ & $\mathbf{A C}$ & $\mathbf{C R}$ \\
\hline $\begin{array}{l}\text { During } \\
\mathrm{H}_{2} \mathrm{O}_{2} \\
\text { addition }\end{array}$ & & & & & $\begin{array}{l}6.2 \\
-8.0\end{array}$ & $\begin{array}{l}6.8 \\
-14.0\end{array}$ \\
\hline Final & 5.9 & 6.6 & 5.8 & 6.8 & 6.7 & 9.5 \\
\hline
\end{tabular}

The $5.0 \mathrm{Fe} / \mathrm{CR}$ and $\mathrm{CR}$ catalysts showed similar performance, resulting in approximately $20 \%$ higher BPA removal and almost 50\% higher TOC conversion when the catalyst load was doubled from the initial $1 \mathrm{~g} \mathrm{~L}^{-1}$ (Table 2). This phenomenon indicates that increase in the $\mathrm{Fe}$ catalyst dose would thus increase the reactive surface area, the amount of iron and hydroxyl radical production that altogether enhance the degradation rate of BPA and TOC conversion [70, 71, 72]. Although the BPA removal was $20-40 \%$ lower when compared to the $2.5 \mathrm{Fe} / \mathrm{CR}$ and $33 \mathrm{Fe} / \mathrm{CR}$ catalysts, the TOC conversion with the $5.0 \mathrm{Fe} / \mathrm{CR}$ and $\mathrm{CR}$ catalysts was higher when the catalyst dose was increased. The $\mathrm{pH}$ values of the carbon slurry before the addition of $\mathrm{H}_{2} \mathrm{O}_{2}$ for the $\mathrm{CR}$ and $5.0 \mathrm{Fe} / \mathrm{CR}$ catalysts were also around neutral or basic, thus differing from the two other catalysts (Table 2). As can be seen in Table 2, the amount of leached iron from the catalysts into the solution from the 5.0Fe/CR and CR catalysts remained insignificant, and therefore, the oxidation reaction with these catalysts was totally heterogeneous. The iron content in the catalysts has been proposed to be a more significant factor than the specific surface area when the catalytic activity is estimated [58]. As observed, the 5.0Fe/CR and CR catalysts have lower iron content, and therefore, it might explain the lower catalytic activity toward the removal of BPA when compared to the $2.5 \mathrm{Fe} / \mathrm{CR}$ and $33 \mathrm{Fe} / \mathrm{CR}$ catalyst. However, the TOC conversion was found to be higher under the neutral to basic conditions. The decomposition of $\mathrm{H}_{2} \mathrm{O}_{2}$ is accelerated under basic conditions up to 9 [70,73], and this might have contributed to the more efficient TOC conversion in the present study. In addition, carbon materials catalyze the decomposition of $\mathrm{H}_{2} \mathrm{O}_{2}$, and especially the basic surface sites of the carbon have been reported to promote faster decomposition of $\mathrm{H}_{2} \mathrm{O}_{2}$, whereas acidic groups inhibit the reaction $[45,46,67,73]$. Surface basicity has been 
related to the increased efficiency of the CWPO process [42, 74].

Referring to the preparation procedure for the $5.0 \mathrm{Fe} / \mathrm{CR}$ catalyst and for the basic nature of the $\mathrm{CR}(\mathrm{pH}$ 9) found in previous studies [57], these results may indicate the presence of more basic surface sites than acidic. Finally, these oxidation results indicate that it is possible to use the biomass-based carbon residue and iron catalyst $(5.0 \mathrm{Fe} / \mathrm{CR})$ supported on the $\mathrm{CR}$ at a wide $\mathrm{pH}$ range (5.5-9) as a catalyst in CWPO.

\subsection{Kinetic Study}

The removal of BPA was further analyzed with a kinetic study that was assumed to be of the first order with respect to its concentration (Figs. 4, 5). Based on this, Eq. (2).

\section{Fig. 4}

Time-dependent BPA reduction during catalytic wet peroxide oxidation where the $33 \mathrm{Fe} / \mathrm{CR}$ catalyst is marked with (open circle), $2.5 \mathrm{Fe} / \mathrm{CR}$ with (filled triangle) and $5.0 \mathrm{Fe} / \mathrm{CR}$ with (filled square). Reaction conditions: $\mathrm{c}(\mathrm{BPA})=60 \mathrm{mg} \mathrm{L}^{-1}, \mathrm{c}\left(\mathrm{H}_{2} \mathrm{O}_{2}\right)=1.5 \mathrm{~g} \mathrm{~L}^{-1}, \mathrm{c}($ catalyst $)=1 \mathrm{~g} \mathrm{~L}^{-1}, \mathrm{~T}=50^{\circ} \mathrm{C}$ and at initial $\mathrm{pH} 5.5-8.5$

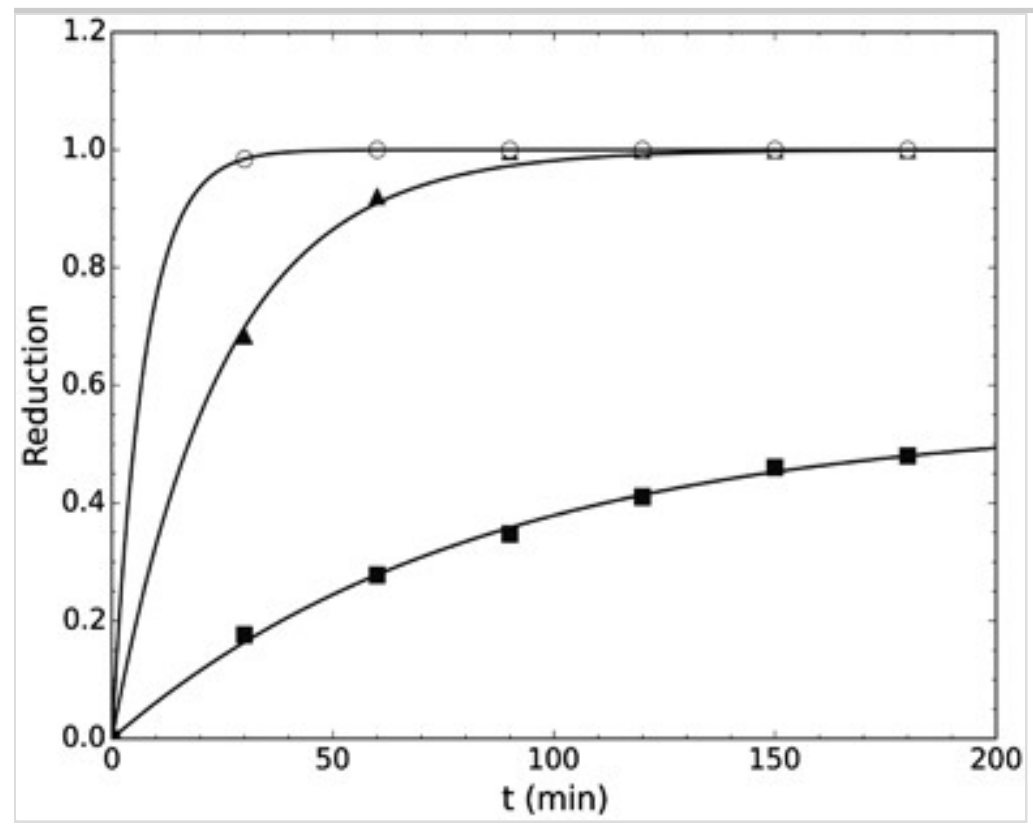

Fig. 5 
Time-dependent BPA reduction during catalytic and non-catalytic wet peroxide oxidation where CR support is marked with (open circle) and the non-catalytic experiment with (filled triangle). Reaction conditions: $\mathrm{c}$ $(\mathrm{BPA})=60 \mathrm{mg} \mathrm{L}^{-1}, \mathrm{c}\left(\mathrm{H}_{2} \mathrm{O}_{2}\right)=1.5 \mathrm{~g} \mathrm{~L}^{-1}, \mathrm{c}(\mathrm{CR})=1 \mathrm{~g} \mathrm{~L}^{-1}, \mathrm{~T}=50^{\circ} \mathrm{C}$ and at initial $\mathrm{pH} 6.2-6.9$

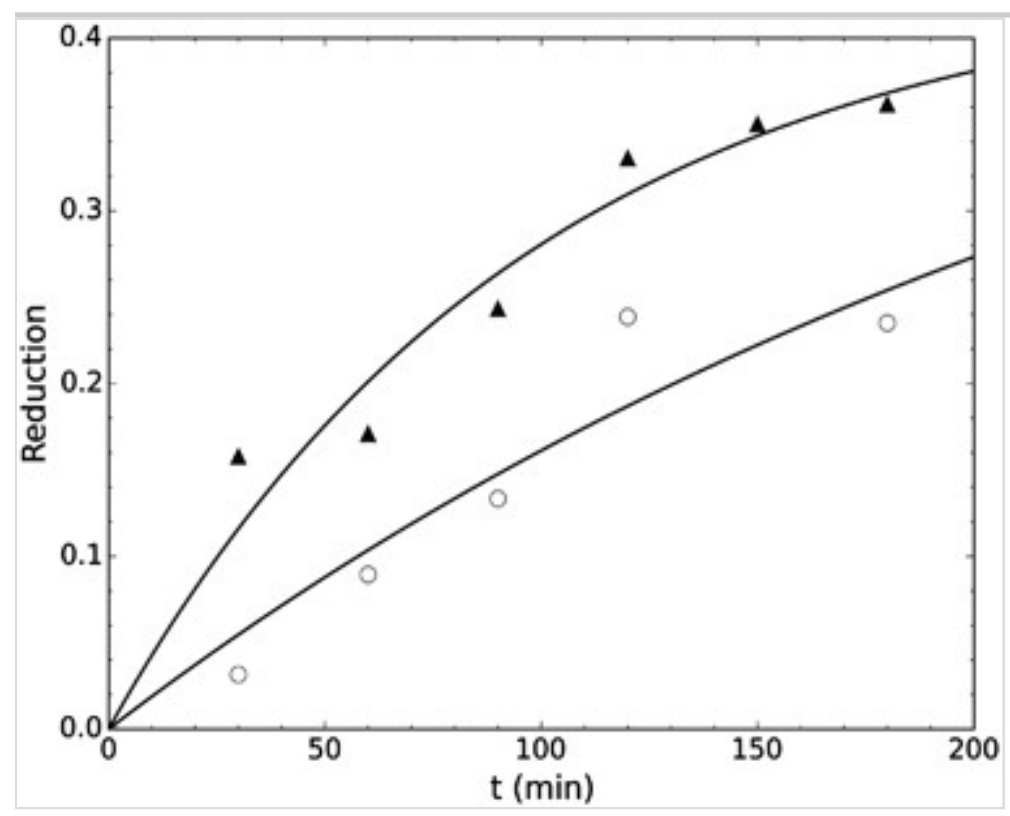

$$
R(t)=R_{T o t}\left(1-e^{-k t}\right)
$$

was fitted to the measured data using a standard non-linear least squares algorithm. Total removal $R_{\text {Tot }}$ and reaction rate constant $k$ were used as fitting parameters. Goodness of fit was evaluated from the calculated $R$ ${ }^{2}$ values and analysis of the residuals. No systematic deviations from the model used in this work were detected for the Fe/CR catalyzed experiments (Fig. 4). The possible rate constants for the $2.5 \mathrm{Fe} / \mathrm{CR}$, $5.0 \mathrm{Fe} / \mathrm{CR}$ and $33 \mathrm{Fe} / \mathrm{CR}$ catalysts were $2.401,0.702$ and $8.316 \mathrm{~h}^{-1}$, respectively. The reduction rate for BPA by the $33 \mathrm{Fe} / \mathrm{CR}$ catalyst was about 11.5 times that of the $5.0 \mathrm{Fe} / \mathrm{CR}$ catalyst. However, as reported in the preceding section, the leaching of iron from the $33 \mathrm{Fe} / \mathrm{CR}$ catalyst was significant (Table 4) whereas no leaching were observed with the 5.0Fe/CR catalyst. For the experiments with only the CR as the catalyst or no catalyst, the achieved fit was much poorer (Fig. 5), and the rate constants for the $\mathrm{CR}$ and non-catalyst experiments were 0.619 and 
$0.218 \mathrm{~h}^{-1}$, respectively. The poor fit was due to the large deviations in the two experiments.

AQ2

\section{Table 4}

LC-MS data detected from the oxidized BPA solution catalyzed by 5.0Fe/CR

\begin{tabular}{|l|l|l|l|l|}
\hline Compound & $\begin{array}{l}\text { Retention } \\
\text { time } \\
\text { (min) }\end{array}$ & [M-H] & Formula & Tentative structure \\
\hline A & 1.92 & 311 & $\mathrm{C}_{17} \mathrm{H}_{12} \mathrm{O}_{6}$ & \\
\hline $\mathrm{B}$ & 2.16 & 229 & $\mathrm{C}_{14} \mathrm{H}_{14} \mathrm{O}_{3}$ & \\
\hline E & 2.37 & 205 & $\mathrm{C}_{12} \mathrm{H}_{14} \mathrm{O}_{3}$
\end{tabular}




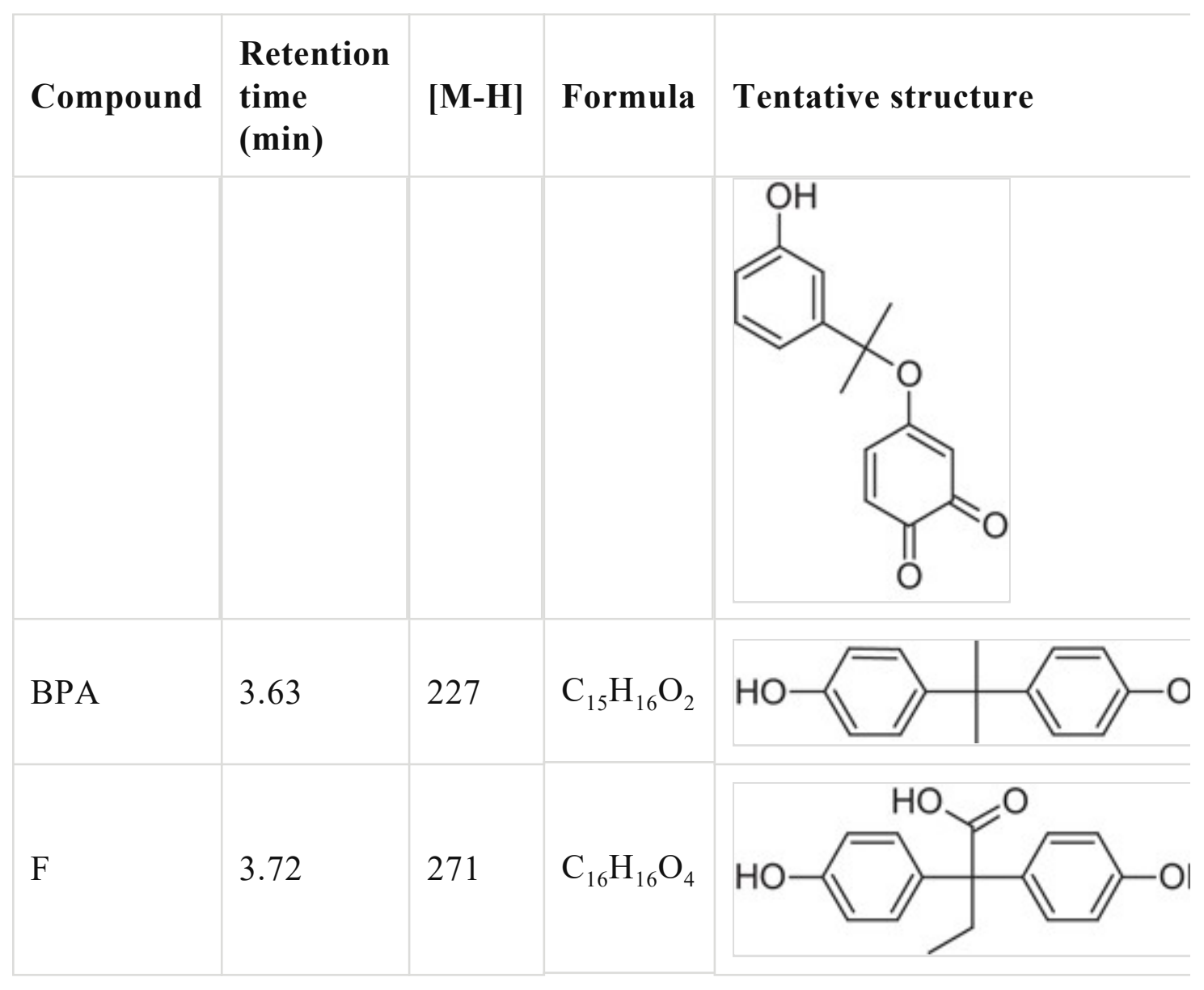

\subsection{Analysis of by-Products}

According to the TOC measurements of the final samples, the removal of organic compounds was not as high as the abatement of BPA during CWPO of BPA (Table 2). For example, in the $5.0 \mathrm{Fe} / \mathrm{CR}$ catalyzed reaction (catalyst concentration $2 \mathrm{~g} \mathrm{~L}^{-1}$ ), the BPA removal was $83 \%$ and TOC conversion was $64 \%$ while the theoretical TOC conversion should have been higher than $80 \%$. The low TOC conversion refers the formation of by-products during the oxidation reaction. According to the literature several intermediates and by-products have been identified after oxidation of BPA. In the study of Gözmen et al. [75] phenols, catechol, quinones, acetic and formic acids were detected after electroFenton treatment of BPA while in the catalytic wet air oxidation of BPA Mezohegyi et al. [76] observed p-hydroxyacetophenone, acetic and formic acids in the final effluent. Therefore, the final samples after the oxidation reactions were analyzed with the liquid chromatography -mass spectrometry (LC-MS) technique. As an example, Fig. 6 presents the chromatogram of the oxidized BPA solution catalyzed by $5.0 \mathrm{Fe} / \mathrm{CR}$. 
In addition to BPA at the retention time of $3.62 \mathrm{~min}$, six peaks of the products named A-F are observed on the spectrum. The lower retention times of five peaks (A-E) refer to the formation of more polar products than BPA during the oxidation process.

\section{Fig. 6}

LC-MS chromatogram of the BPA solution after $3 \mathrm{~h}$ of wet peroxide oxidation catalyzed by $5.0 \mathrm{Fe} / \mathrm{CR} 2 \mathrm{~g} \mathrm{~L}^{-1}$

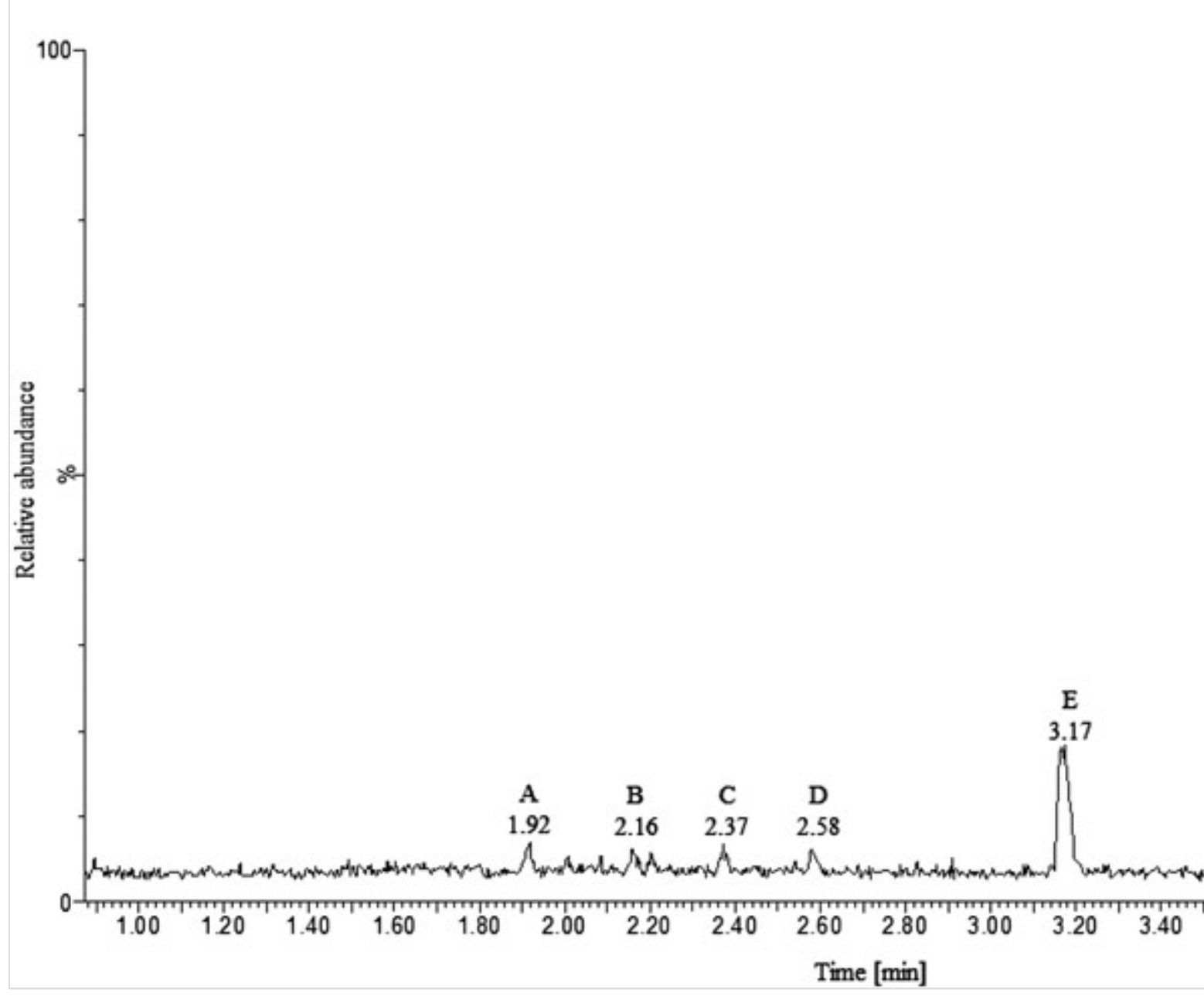

Table 4 lists the [M-1] ions in the negative mode of LC-MS, the detected molecular formulas and the tentative structures of the compounds. Surprisingly, only one of the products, compound C, has a molecular weight lower than BPA and no carboxylic acids were detected. However, this was probably due to the analyzing method because in the study of Mezohegyi et al. [76] acetic and formic acids were analyzed by ion chromatogram. Products B and D have a slightly 
higher molecular weight than BPA $\left(230 \mathrm{~g} \mathrm{~mol}^{-1}\right)$. According to the tentative structures of these compounds, a reaction between oxidized products (methanol and some other intermediate) has probably formed these structures. Products E and F are most obviously formed in the reaction between BPA and the reactive hydrogen radical. Therefore, the $\mathrm{Fe} / \mathrm{CR}$ catalyzed $\mathrm{H}_{2} \mathrm{O}_{2}$ oxidation of BPA in to the by-products described in Table 4 happens probably through to the hydroxyl radical $(\cdot \mathrm{OH})$ oxidation which is also proposed in the study of Cleveland et al. [56]. The proposed pathway for Fenton oxidation of BPA is described e.g. in the study of Poerschmann et al. [21] and Luo et al. [77]. Moreover, similar by-products have been identified in several studies $[21,78,79$, 80] However, the chromatogram shows (Fig. 6) that the relative abundance of compounds A-D is much lower than the BPA concentration, which causes inaccurate results. Therefore, the proposed molecular structures of these compounds are only tentative. The possible toxicity of the identified by-products was examined from the literature. Due to the phenolic structure of all by-products they may be estrogenic active [81]. However, Ye et al. [82] have been reported that the catechol structure of BPA has three times lower estrogenic activity than that of BPA in MCF-7 cells. Therefore, the compound A with the catechol structure could have lower estrogenic activity than the BPA. Moreover, in the study of Kitamura et al. [81] the estrogenic activity of BPA-related compounds was studied in both MCF-7 cells and ovariectomized mice. They observed that hydroxylated propane groups decreased the estrogenic activity i.e. isomers B and D with propane bridge groups could be less toxic than BPA. Furthermore, quinone derivate of BPA (compound E) could probably be more toxic than BPA itself due to the potential mutagenicity of such compounds [83, 84].

\subsection{Characterization of Used Catalysts}

Table 5 summarizes the iron content, the BET surface area, as well as the relative pore size distribution of the catalysts. Compared to the fresh catalysts (Table 1), the $\mathrm{Fe}$ content of the $2.5 \mathrm{Fe} / \mathrm{CR}$ and $5.0 \mathrm{Fe} / \mathrm{CR}$ catalysts remained stable, although the first showed significant leaching of iron in the liquid phase after the CWPO reaction. The used preparation method (multiple impregnation under acidic conditions) for the $2.5 \mathrm{Fe} / \mathrm{CR}$ might have had a negative impact for the iron 
impregnation. The longer impregnation time have been attributed to reduce the iron impregnation due to the exchange of iron ions by protons $\left(\mathrm{H}^{+}\right)$under acidic conditions $[85,86]$. Furthermore, during the impregnation there might have been competition between the adsorbed iron ions and aqueous iron ions which lowers the iron impregnation. The BET surface area remained almost unchanged, and the increase observed with the $33 \mathrm{Fe} / \mathrm{CR}$ catalyst is due to the iron leaching (Table 2). These results are somewhat ambiguous in the case of the $2.5 \mathrm{Fe} / \mathrm{CR}$ catalyst because the results for the BET surface area would imply that iron would have remained (i.e., the area did not change) rather than it being leached. Therefore, it could be hypothesized because the used CR support was non-homogenous material (see Fig. 3), not only the bulk content of iron but also the amount of leached iron varied. Thus, during the oxidation reaction the $\mathrm{H}_{2} \mathrm{O}_{2}$ dissolved the organic carbon from the $\mathrm{CR}$ support and thus may have released iron from the bulk content easier. This hypothesis is supported by the ICPOES result, from which it can be observed that the iron content was reduced when the used CR (Table 5) is compared to fresh CR (Table 1). In the case of $\mathrm{AC}$ and $\mathrm{CR}$, the surface area was decreased which might be due to the pore blockage caused by agglomeration of pollutants [87] and/or it might be the result of the adsorbed BPA on the surface. Microand mesopores are the most effective for removing organic pollutants [88]. The $2.5 \mathrm{Fe} / \mathrm{CR}$ and $\mathrm{CR}$ catalysts had the largest volumes of pores when the micro- and mesopore volumes were combined (83.6 and $83.5 \%$, respectively) whereas AC had the smallest (27.3\%). The microand mesopore volumes increased almost every used catalyst compared to the pore volumes of the fresh catalysts (Table 1). For the $2.5 \mathrm{Fe} / \mathrm{CR}$ and $5.0 \mathrm{Fe} / \mathrm{CR}$ and $\mathrm{CR}$ catalysts, the increase was less than $2 \%$ while the highest increase was found for $\mathrm{AC}(7.5 \%)$ and was $4 \%$ for the $33 \mathrm{Fe} / \mathrm{CR}$ catalyst. This might be due to the leaching of iron (and other compounds) from the catalyst active sites during the experiments. The total pore volumes remained steady for the $2.5 \mathrm{Fe} / \mathrm{CR}$ and $5.0 \mathrm{Fe} / \mathrm{CR}$ catalysts and for the CR, while a 31 and $25 \%$ decrease was found in $\mathrm{AC}$ and $33 \mathrm{Fe} / \mathrm{CR}$, respectively. Again, this might be due to the pore blockage of these materials. 
Iron content, BET surface area, total pore volume and relative distribution of the micro-, meso- and macropores of used catalysts

\begin{tabular}{|c|c|c|c|c|c|c|}
\hline Catalyst & $\begin{array}{l}\text { Fe- } \\
\text { content } \\
(\%)\end{array}$ & $\begin{array}{l}\text { BET } \\
\text { surface } \\
\text { area }\left(\mathrm{m}^{2}\right. \\
\left.\mathrm{g}^{-1}\right)\end{array}$ & $\begin{array}{l}\text { Total pore } \\
\text { volume } \\
\left(\mathrm{cm}^{3} \mathrm{~g}^{-1}\right)\end{array}$ & $\begin{array}{l}V_{\text {Micro }} \\
(\%)\end{array}$ & $\begin{array}{l}V_{\text {Meso }} \\
(\%)\end{array}$ & $\begin{array}{l}V_{\text {Makro }} \\
(\%)\end{array}$ \\
\hline $2.5 \mathrm{Fe} / \mathrm{CR}$ & 4.8 & 64.0 & 0.093 & 5.40 & 79.5 & 15.1 \\
\hline $5.0 \mathrm{Fe} / \mathrm{CR}$ & 5.0 & 67.0 & 0.096 & 7.30 & 79.2 & 13.5 \\
\hline $33 \mathrm{Fe} / \mathrm{CR}$ & - & 55.1 & 0.098 & 5.10 & 68.4 & 26.5 \\
\hline $\mathrm{AC}$ & 0.21 & 721 & 0.298 & 20.8 & 69.8 & 9.40 \\
\hline $\mathrm{CR}$ & 0.06 & 58.8 & 0.100 & 5.00 & 81.0 & 14.0 \\
\hline
\end{tabular}

Figure 7 presents X-ray diffractograms for the used catalysts. Compared to the diffractograms of the fresh CR support and catalysts (Fig. 1), the $\mathrm{X}$-ray diffractograms for the $\mathrm{CR}, 2.5 \mathrm{Fe} / \mathrm{CR}$ and $33 \mathrm{Fe} / \mathrm{CR}$ catalysts show no significant changes. This suggests that the support material and these catalysts are stable materials. The reflections obtained for the $5.0 \mathrm{Fe} / \mathrm{CR}$ catalyst at $2 \theta 29.3^{\circ}, 31.7^{\circ}$ and $36.6^{\circ}$ correspond to $\mathrm{Fe}_{3} \mathrm{O}_{4}$ (JCPDS: 00003-0863) and indicate that $\mathrm{NaCl}$ was leached during the CWPO process. The EDS analysis confirmed this result: No sodium or chloride was detected in the used 5.0Fe/CR catalyst. In addition, the presence of iron $(7.55 \mathrm{wt} \%)$ was detected. Figure 8 presents the FESEM images of the used catalysts, and they were in good agreement with the results presented. Similarly, the porous and layered structure was clearly seen as well as the heterogeneously dispersed iron particles $(<<1 \mu \mathrm{m})$ when compared to the FESEM images obtained for the fresh catalyst (Fig. 3).

\section{Fig. 7}

X-ray diffractograms of the used carbon residue support (1) and $\mathrm{Fe}$ catalysts (2-4). (plus) JCPDS:01-078-3262 $\left(\mathrm{CaCO}_{3}\right)$; (asterisk) JCPDS: 00-003-0863 $\left(\mathrm{Fe}_{3} \mathrm{O}_{4}\right)$; (double quotes) JCPDS: 01-089-0597 $\left(\mathrm{Fe}_{2} \mathrm{O}_{3}\right)$; (hash) JCPDS: 04-015-9580 $\left(\mathrm{Fe}_{2} \mathrm{O}_{3}\right)$ 


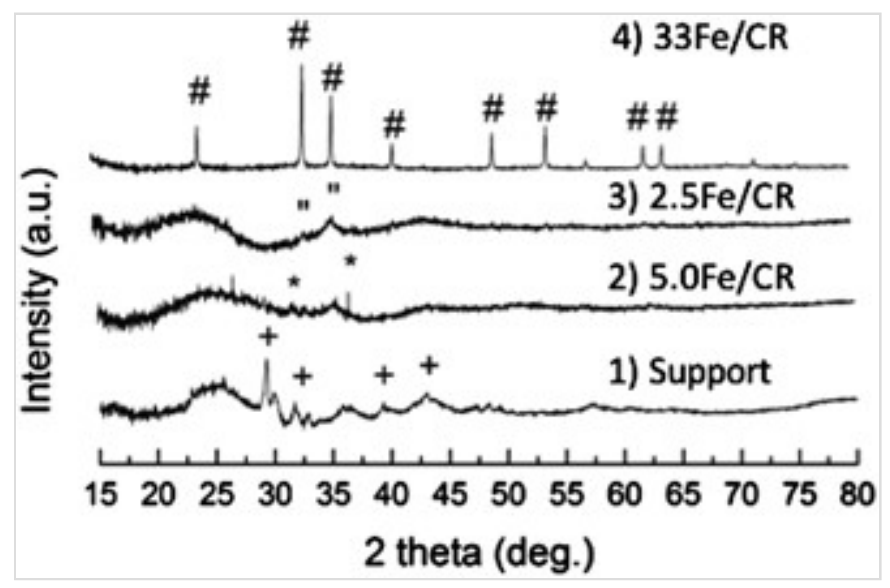

Fig. 8

SEM images of used, a $2.5 \mathrm{Fe} / \mathrm{CR}, \mathbf{b} 5.0 \mathrm{Fe} / \mathrm{CR}, \mathbf{c} 33 \mathrm{Fe} / \mathrm{CR}$ and $\mathbf{d} \mathrm{CR}$ catalysts (magnification $\times 5000$ ). The porous structure $(\mathbf{b})$ and the iron particles (c) are marked with an arrow

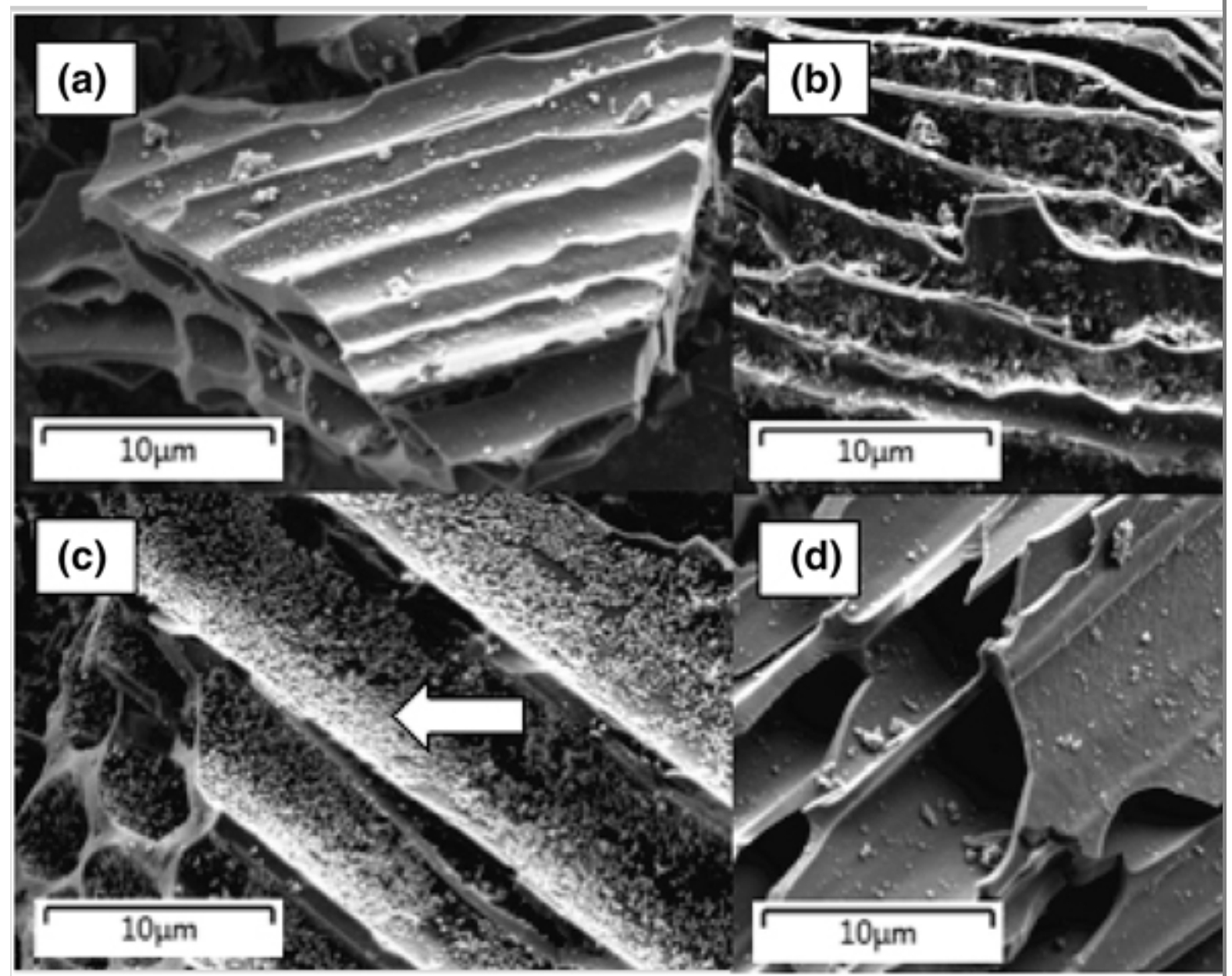

\section{Conclusions}


Three iron catalysts were prepared by using a biomass-based CR as the support. One $\mathrm{Fe}$ catalyst $(2.5 \mathrm{Fe} / \mathrm{CR})$ was prepared with incipient wet impregnation and two $\mathrm{Fe}$ catalysts $(5.0 \mathrm{Fe} / \mathrm{CR}$ and $33 \mathrm{Fe} / \mathrm{CR})$ with wet impregnation with an iron chloride solution. The degradation of BPA was studied using the prepared Fe catalysts in CWPO experiments. The iron impregnation to the CR support decreased the BET surface area values that varied between the catalysts from 17 to $66 \mathrm{~m}^{2} \mathrm{~g}^{-1}$. For the CR support, the BET surface area value was $91 \mathrm{~m}^{2} \mathrm{~g}^{-1}$. The catalyst $5.0 \mathrm{Fe} / \mathrm{CR}$ was concluded to be the best catalyst. It was found to be the most stable catalyst as a result of negligible iron leaching during the $3 \mathrm{~h}$ experiment. In addition, the $5.0 \mathrm{Fe} / \mathrm{CR}$ catalyst showed lower oxidation activity than $2.5 \mathrm{Fe} / \mathrm{CR}$ and $33 \mathrm{Fe} / \mathrm{CR}$, but the TOC conversion were 15 $-20 \%$ higher. These oxidation results indicate that the biomass-based carbon residue-supported $5.0 \mathrm{Fe} / \mathrm{CR}$ can be used as a catalyst, and pure carbon residue can be used as a catalyst in CWPO in the degradation of BPA. With this material, it is possible to operate up to a $5.5 \mathrm{pH}$ value close to 9 using 5.0Fe/CR and $\mathrm{CR}$ as catalysts.

AQ3

\section{Acknowledgements}

The authors gratefully acknowledge the Academy of Finland for providing research funding, AOPI project (263397) within the research program for Sustainable Governance of Aquatic Resources (AKVA). The Tauno Tönning Foundation is gratefully acknowledged for its financial support. The authors would like to thank PhD Henrik Romar for the BET, pore size and pore volume measurements and Jaakko Pulkkinen (AAS) and Tuomas Vähätiitto (TOC). We also thank the staff at TraceElement Laboratory at the University of Oulu for their assistance with the elementary analysis. Lotta Hekkala and Aleksanteri Nikula are acknowledged for their support during the laboratory work.

\section{References}

1. Selvaraj KK, Shanmugam G, Sampath S, Joakim Larsson DG, Ramaswamy BR (2014) Ecotoxicol Environ Saf 99:13-20 
2. Belfroid A, Van Velzen M, Van der Horst B, Vethaak D (2002) Chemosphere 49:97-103

3. Välitalo P, Perkola N, Seiler T, Sillanpää M, Kuckelkorn J, Mikola A, Hollert H, Schultz E (2016) Water Res 88:740-749

4. Campbell CG, Borglin SE, Green FB, Grayson A, Wozei E, Stringfellow WT (2006) Chemosphere 65:1265-1280

5. Nelson J, Bishay F, van Roodselaar A, Ikonomou M, Law FCP (2007) Sci Total Environ 374:80-90

6. Jurado A, Vàzquez-Suñé E, Carrera J, López de Alda M, Pujades

E, Barceló D (2012) Sci Total Environ 440:82-94

7. Luo Y, Guo W, Ngo HH, Nghiem LD, Hai FI, Zhang J, Liang S, Wang XC (2014) Sci Total Environ 473-474:619-641

8. Gültekin I, Ince NH (2007) J Environ Manage 85:816-832

9. United States Environmental Protection Agency. (1998).

Endocrine disruptor testing and screening advisory committee (EDSTAC). Final report. washington, DC, US

10. Yamamoto T, Yasuhara A, Shiraishi H, Nakasugi O (2001) Chemosphere 42:415-418

11. Ying G, Kookana RS, Kumar A, Mortimer M (2009) Sci Total Environ 407:5147-5155

12. PlasticsEurope (2007) Applications of bisphenol A.

Polycarbonate/bisphenol A (BPA) groups of industry association PlasticsEurope. http://www.bisphenol-a-

europe.org/uploads/applications\%20of\%20BPA\%20Sept\%2008.pdf

13. Staples CA, Dorn PB, Klecka GM, O'Block ST, Harris LR (1998) Chemosphere 36:2149-2173 
14. Seachrist DD, Bonk KW, Ho S, Prins GS, Soto AM, Keri RA (2016) Reprod Toxicol 59:167-182

15. Levy G, Lutz I, Krüger A, Kloas W (2004) Environ Res 94:102 $-111$

16. Markey CM, Coombs MA, Sonnenschein C, Soto AM (2003) Evol Dev 5:67-75

17. Richter CA, Birnbaum LS, Farabollini F, Newbold RR, Rubin BS, Talsness CE, Vandenbergh JG, Walser-Kuntz DR, vom Saal FS (2007) Reprod Toxicol 24:199-224

18. Li G, Lu Y, Lu C, Zhu M, Zhai C, Du Y, Yang P (2015) J Hazard Mater 294:201-208

19. Ioan I, Wilson S, Lundanes E, Neculai A (2007) J Hazard Mater $142: 555-558$

20. Katsumata H, Kawabe S, Kaneco S, Suzuki T, Ohta K (2004) J Photochem Photobiol A Chem 162:297-305

21. Poerschmann J, Trommler U, Górecki T (2010) Chemosphere 79:975-986

22. Kwon J, Lee B (2015) Chem Eng Res Design 104:519-529

23. Cesaro A, Naddeao V, Belgiorno V (2013) J Bioremed Biodeg $4: 208$

24. Neyens E, Baeyens J (2003) J Hazard Mater 98:33-50

25. Huling SG, Kan E, Wingo C (2009) Appl Catal B Environ 89:651-658

26. Perathoner S, Centi G (2005) Top Catal 33:207-224 
27. Li J, Gu J, Li H, Liang Y, Hao Y, Sun X, Wang L (2010)

Microporous Mesoporous Mater 128:144-149

28. Gomes HT, Miranda SM, Sampaio MJ, Silva AMT, Faria JL (2010) Catal Today 151:153-158

29. Gomes HT, Miranda SM, Sampaio MJ, Figueiredo JL, Silva AMT, Faria JL (2011) Appl Catal B Environ 106:390-397

30. Centi G, Perathoner S, Torre T, Verduna MG (2000) Catal Today 55:61-69

31. Melero JA, Martínez F, Botas JA, Molina R, Pariente MI (2009) Water Res 43:4010-4018

32. Fenton HJH (1894) J Chem Soc 65:899-910

33. Pignatello JJ, Oliveros E, MacKay A (2006) Crit Rev Environ Sci Technol 36:1-84

34. Zazo JA, Casas JA, Mohedano AF, Rodríguez JJ (2006) Appl Catal B Environ 65:261-268

35. Messele SA, Soares OSGP, Órfão JJM, Stüber F, Bengoa C, Fortuny A, Fabregat A, Font J (2014) Appl Catal B Environ 154 $-155: 329-338$

36. Navalon S, Alvaro M, Garcia H (2010) Appl Catal B Environ 99:1-26

37. Zhang X, Ding Y, Tang H, Han X, Zhu L, Wang N (2014) Chem Eng J 236:251-262

38. Ramirez JH, Costa CA, Madeira LM, Mata G, Vicente MA, Rojas-Cervantes ML, López-Peinado AJ, Martín-Aranda RM (2007) Appl Catal B 71:44-56 
39. Gemeay AH, Mansour IA, El-Sharkawy RG, Zaki AB (2003) J Mol Catal A Chem 193:109-120

40. Rodríguez-Reinoso F (1998) Carbon 36:159-175

41. Rey A, Faraldos M, Casas JA, Zazo JA, Bahamonde A, Rodríguez JJ (2009) Appl Catal B Environ 86:69-77

42. Ribeiro AR, Nunes OC, Pereira MFR, Silva AMT (2015) Environ Int 75:33-51

43. Bautista-Toledo I, Ferro-García MA, Rivera-Utrilla J, MorenoCastilla C, Fernández FJV (2005) Environ Sci Technol 39:6246 $-6250$

44. Chang Q, Lin W, Ying W (2010) J Hazard Mater 184:515-522

45. Santos VP, Pereira MFR, Faria PCC, Órfão JJM (2009) J Hazard Mater 162:736-742

46. Oliveira LCA, Silva CN, Yoshida MI, Lago RM (2004) Carbon 42:2279-2284

47. The European parliament and the council of the European Union (2008). Directive 2008/98/ec., 2008. http://eur-lex.europa.eu/legalcontent/EN/TXT/?qid=1472559001854\&uri=CELEX:32008L0098

48. Martínez ML, Torres MM, Guzmán CA, Maestri DM (2006) Ind Crops Prod 23:23-28

49. Jagtoyen M, Derbyshire F (1998) Carbon 36:1085-1097

50. Tancredi N, Medero N, Möller F, Píriz J, Plada C, Cordero T 2004 J Colloid Interface Sci 279:357-363

51. Ribeiro RS, Silva AMT, Figueiredo JL, Faria JL, Gomes HT (2016) Appl Catal B 187:428-460 
52. Choi J, Kim T, Choo K, Sung J, Saidutta MB, Ryu S, Song S, Ramachandra B, Rhee Y (2005) Appl Catal A Gen 290:1-8

53. Zhong Y, Li G, Zhu L, Yan Y, Wu G, Hu C (2007) J Mol Catal A 272:169-173

54. Ramirez JH, Maldonado-Hódar FJ, Pérez-Cadenas AF, MorenoCastilla C, Costa CA, Madeira LM (2007) Appl Catal B Environ 75:312-323

55. Rodríguez A, Ovejero G, Sotelo JL, Mestanza M, García J (2010) Ind Eng Chem Res 49:498-505

56. Cleveland V, Bingham J, Kan E (2014) Sep Purif Technol 133:388-395

57. Kilpimaa S, Kuokkanen T, Lassi U (2013) BioResources 8:1011 $-1027$

58. Domínguez CM, Quintanilla A, Ocón P, Casas JA, Rodriguez JJ (2013) Carbon 60:76-83

59. Dastgheib SA, Ren J, Rostam-Abadi M, Chang R (2014) Appl Surf Sci 290:92-101

60. Rey A, Faraldos M, Bahamonde A, Casas JA, Zazo JA, Rodríguez JJ (2008) Ind Eng Chem Res 47:8166-8174

61. Tsoncheva T, Velinov N, Ivanova R, Stoycheva I, Tsyntsarski B, Spassova I, Paneva D, Issa G, Kovacheva D, Genova I (2015) Microporous Mesoporous Mater 217:87-95

62. Williams DH, F. I (1995) Spectroscopic methods in organic chemistry, 5th edn. McGraw-Hill publishing, Berkshire, pp 41-45

63. Mao W, Ma H, Wang B (2009) J Hazard Mater 167:707-712 
64. Romanos J, Beckner M, Stalla D, Tekeei A, Suppes G, Jalisatgi S, Lee M, Hawthorne F, Robertson JD, Firlej L (2013) Carbon $54: 208-214$

65. Radovic LR, Mureno-Castilla C, Rivera-Utrilla J. (2001). Carbon materials as adsorbents in aqueous solutions. In MarcelDekker (ed), Chemistry and physics of carbon, Marcel-Dekker, New York, pp. 227-405

66. Catrinescu C, Teodosiu C, Macoveanu M, Miehe-Brendlé J, Le Dred R (2003) Water Res 37:1154-1160

67. Lücking F, Köser H, Jank M, Ritter A (1998) Water Res $32: 2607-2614$

68. Timofeeva MN, Khankhasaeva ST, Badmaeva SV, Chuvilin AL, Burgina EB, Ayupov AB, Panchenko VN, Kulikova AV (2005) Appl Catal B 59:243-248

69. Sabhi S, Kiwi J (2001) Water Res 35:1994-2002

70. Huang YQ, Wong CKC, Zheng JS, Bouwman H, Barra R, Wahlström B, Neretin L, Wong MH (2012) Environ Int 42:91-99

71. Hermanek M, Zboril R, Medrik I, Pechousek J, Gregor C (2007) J Am Chem Soc 129:10929-10936

72. Sun S, Lemley AT (2011) J Mol Catal A Chem 349:71-79

73. Khalil LB, Girgis BS, Tawfik TAM (2001) J Chem Technol Biotechnol 76:1132-1140

74. Rey A, Zazo JA, Casas JA, Bahamonde A, Rodriguez JJ (2011) Appl Catal A Gen 402:146-155

75. Gözmen B, Oturan MA, Oturan N, Erbatur O (2003) Environ Sci Technol 37:3716-3723 
76. Mezohegyi G, Erjavec B, Kaplan R, Pintar A (2013) Ind Eng Chem Res 52:9301-9307

77. Luo S, Yang S, Sun C, Wang X (2011) Water Res 45:1519 $-1528$

78. Chakma S, Moholkar VS (2014) Ind Eng Chem Res 53:6855 $-6865$

79. Deborde M, Rabouan S, Mazellier P, Duguet J, Legube B (2008) Water Res 42:4299-4308

80. Kondrakov AO, Ignatev AN, Frimmel FH, Bräse S, Horn H, Revelsky AI (2014) Appl Catal B Environ 160-161:106-114

81. Kitamura S, Suzuki T, Sanoh S, Kohta R, Jinno N, Sugihara K, Yoshihara S, Fujimoto N, Watanabe H, Ohta S (2005) Toxicol Sci 84:249-259

82. Ye X, Zhou X, Needham LL, Calafat AM (2011) Anal Bioanal Chem 399:1071-1079

83. Edmonds JS, Nomachi M, Terasaki M, Morita M, Skelton BW, White AH (2004) Biochem Biophys Res Commun 319:556-561

84. Atkinson A, Roy D (1995) Biochem Biophys Res Commun 210:424-433

85. Park H, Koduru JR, Choo K, Lee B (2015) J Hazard Mater 286:315-324

86. Koduru JR, Lingamdinne LP, Singh J, Choo K- (2016) Process Saf Environ Prot 103:87-96

87. Lu X, Jiang J, Sun K, Xie X, Hu Y (2012) Appl Surf Sci 258:8247-8252 
88. Li Q, Snoeyink VL, Mariñas BJ, Campos C (2003) Water Res $37: 4863-4872$ 